\title{
The impact of COVID-19 pandemic on the Malaysian firms' operation
}

\author{
Fazlollah Keshavarzi, Berry Ting Wei Qi, Betty Tang Zhi Xin, Chang Kai Xin, Chee Fei San and Chen Kar Mey
}

\section{Clinical Pharmacy Department, Faculty of Pharmaceutical Sciences, UCSI University, Malaysia}

*. Corresponding author: Fazlollah Keshavarzi, Clinical Pharmacy Department, Faculty of Pharmaceutical Sciences, UCSI University, Malaysia. E-mail: fazlollahk @yahoo.com.

Cite this article: Keshavarzi, F.; Ting, B.W.Q.; Tang, B.Z.X.; Chang, K.X.; Chee, F.S.; Chen, K.M. The impact of COVID-19 pandemic on the Malaysian firms' operation. Int J Epidemiol Health Sci 2021;2(6): e12. Doi:10.51757/IJEHS.2.6.2021.244125.

\begin{abstract}
Background. The worldwide economic impact of the COVID-19 pandemic is comparable with the largest disastrous events of modern human history, such as the first and second world wars. This study investigated the nationwide impact of the pandemic on the local Malaysian firms.

Methods. A cross-sectional, online survey was carried out in East and West Malaysia by inviting the Malaysian firms' executives to fill in a questionnaire that was adopted from previous similar studies in other countries. The final questionnaire included 16 questions distributed in three categories. The executives of firms were contacted through email and social media. SSPS was used to analyse the collected data.

Results. A total of 379 responses were received. Nearly $42 \%$ of firms reported a small impact with some difficulties in business operations but overall stability. Approximately $32 \%$ of businesses were severely impacted, and operations were barely maintained. Six percent of the firms had no significant difficulties and 5.3\% reported that the pandemic provided new opportunities for development.

Conclusion. Almost one-third of the Malaysian firms are affected significantly by the COVID-19 pandemic. The business operation of half of the Malaysian firms is also affected to some extent. Supportive policies are needed to reduce the companies' manufacturing costs and assist them in surviving and eventually returning to normal business operations.
\end{abstract}

Keywords: COVID-19 Pandemic, Economic Burden of Disease, Malaysia

\section{Introduction}

COVID-19, being a global pandemic and public health crisis, has caused a great impact on the global economy. This includes a significant decrease in income, an increase in the unemployment rate, disruptions in the supply chain, as well as losses mainly in the transportation and service industries, such as tourism and hospitality due to travel restrictions (1). It has also caused many firms and factories to cease operations. In addition, consumers have reduced their spending due to a reduction in income and household finance (2).
The impact of the COVID-19 pandemic has been different on the economies of different countries. China has been the only country in the world with a Gross Domestic Product (GDP) growth in 2020 (lowest growth rate recorded since 1976) (3) whereas the GDP of the United States dropped by $2.3 \%$ in the same year (4). In Malaysia, the Movement Control Order (MCO), which was effective from 18 March 2020, dramatically affected some of the industries

such as tourism, aviation, and construction (5). In the first phase of MCO from March $18^{\text {th }}$ to May $3^{\text {rd }}$ of 2020, Malaysia lost an estimated 2.4 billion Malaysian Ringgit (RM) daily, with a total of RM 63 billion, as 
all the business activities were suspended. As stated by the Malaysian Ministry of Finance, Malaysia's GDP was expected to contract by $4.5 \%$ in 2020 , before regaining its growth in 2021 of $6.5 \%$ to $7.5 \%$. The execution and successive extension of the MCO have greatly influenced Malaysia's economic performance (4). On the other hand, the pandemic has resulted in a $40 \%$ rise in internet purchases of fast-moving consumer products. Malaysian market behaviour may have shifted because of the COVID-19 pandemic, resulting in the establishment of a new normal, such as increased familiarity with internet purchases and cashless or contactless payment transactions (6). The lack of independent academic surveys about the impact of the COVID-19 pandemic on the Malaysian private sector firms and entrepreneurs was the motive of the authors of this article. It is expected that the economic impact of the pandemic will be different from country to country, due to the strength of the national economy, infrastructure, and the magnitude of national savings. Therefore, a nationwide survey may shed light on the diversity of the impact and subsequently allow policymakers to gauge and adjust their assistance and incentives towards the Malaysian firms. Such a survey can also feed the global and regional evaluations of the economic impacts of the current pandemic.

\section{Methods}

This is a nationwide online questionnaire-based survey that was conducted from 19 February 2021 to 25 March 2021 and was approved by the Faculty Research and Scholarly Activities (FRSA), Faculty of Pharmaceutical Sciences, UCSI University. Considering a 5\% margin of error and confidence level of $95 \%$, the required sample size was calculated as 384 firms (http://www.raosoft.com/samplesize.html). The firms had to be registered in Malaysia and run the activities within Malaysia. The questionnaire was developed, validated, and piloted by the United Nations Development Program (UNDP) in China. The English version of the questionnaire was used in the present study $(7,8)$. It consisted of 16 questions, distributed in three categories: demographic characteristics (3 questions); the impact of COVID-19 on firms (7 questions); possible resolution to the impact of COVID-19 on the firms (6 questions).

Due to the large size of the target group and difficulty in obtaining the sampling frame, the authors decided to run a convenience sampling. The executives of

firms were identified through the firms' websites or social media web pages. They were contacted and invited to answer the questionnaire on 'Google Form', an online survey platform. Participation in the survey was completely voluntary, and each participant signed a consent form. Prior to data collection, the study's aims, the confidentiality of individual information, and other ethical concerns stated in the survey guidelines were explained to the participants.

The data analysis was performed by using IBM SPSS ${ }^{\circledR}$ version 22. Descriptive statistics were deployed to report the frequencies and percentages. The correlation between the independent variables and categorical and nominal data was investigated by Pearson's $\chi^{2}$ test of correlation with 0.05 as the cut of point for significance.

The project was approved by Faculty Research and Scholarly Activities (FRSA), Faculty of Pharmaceutical Sciences, UCSI University.

\section{Results}

\section{Firms' Demographics}

Of 550 invitees, 387 responses were received, of which 8 participants were excluded due to inability to categorize them under the listed industries. 292 (77.1\%) of the collected responses were coming from West Malaysia (Peninsula) and 87 (22.9\%) from East Malaysia.

The respondents' industries could be classified as food and beverages 74 firms (19.5\%), education/training/research 40 firms $(10.6 \%)$, clothing/textile 34 firms $(9.0 \%)$, tourism/hotel 25 firms $(6.6 \%)$, healthcare 22 firms (5.8\%), technology/IT 16 firms (4.2\%), wholesale/retail 15 firms (4.0\%), automotive/spare parts 15 firms (4.0\%), cosmetics 15 firms (4.0\%), manufacturing/production 14 firms $(3.7 \%)$, transportation/logistics 14 firms (3.7\%), banking/finance/insurance 14 firms (3.7\%), accounting/auditing 13 firms (3.4\%), and construction/engineering 13 firms (3.4\%). Other industries accounted for $14.4 \%$.

A total of 245 firms, accounted for $63.6 \%$ of all firms, had 50 employees or fewer, 86 firms $(22.4 \%)$ with 50500 employees, 44 firms $(11.4 \%)$ with 501-5000 employees, and 10 firms (2.6\%) with 5000 employees or more.

\section{The impact of the pandemic on firms}

160 firms $(42.2 \%)$ reported that they had experienced a small impact with some difficulties in business operations, but they could maintain overall stability. 123 firms $(32.5 \%)$ faced great impact, operations barely maintained; 23 firms $(6.0 \%)$ had no significant impact and 20 firms $(5.3 \%)$ had a positive impact, providing new opportunities for development (Table 1). 
The Pearson's $\chi^{2}$ test of correlation did not show a significant association between the location or number of employees of the firms with the intensity of the negative impact. Further post-hoc computation of the power of the test by $G$ Power software (version 3.1.9.7, Institute for Digital Research \& Education, UCLA) indicated the power was above $80 \%$. The same post-hoc power analysis was applied to all subsequent non-significant results with similar outcome. However, the type of industry was significantly correlated with the concerned effect $\left(\chi^{2}=108.486\right.$, df $=45, P=0.000$ ).

In response to the question about the main operating pressures that the firms had been facing, the most problematic aspect of operation was reported to be the cancellation of orders, followed by paying the employee salaries and insurance fees (Figure 1).

The greatest reported impact of the pandemic on firm's technological innovation was failure in interdepartmental cooperation, as $43.8 \%$ of the firms responded. However, 103 firms (27.2\%) are determined to invest more in technological innovation after being better aware of the firm's self-development problems (Table 2).

The impact of the pandemic on recruitment has been mainly via the postponement or cancelation of the existing recruitment plan and this involved approximately 191 firms (50.4\%). However, 92 firms $(24.3 \%)$ transitioned to online recruitment. Some others were unable to find a suitable recruitment channel and a minority recruited new manpower, despite increased labour costs resulting from this pandemic (Figure 2). Regarding the firm's plans for changing the manpower size, $170(44.2 \%)$ respondents stated that they will remain at the current size. About $50 \%$ of the respondents were planning to reduce the number of employees, either slightly or greatly.

The impact of the pandemic on supply chain raw materials and accessories was the subject of another question. Where almost $57 \%$ of respondents did not experience serious shortages, the remaining $43 \%$ have had difficulties in maintaining their routine activities (Table 3).

There have been some firms that reported positive impacts, although the pandemic has impacted the whole economy, negatively. The major positive impact of the pandemic is enhanced information and digital construction of firms which is recorded by 171 firms $(45.1 \%)$. Besides that, 141 firms $(37.2 \%)$ believed that the pandemic helped to better realize their firms' shortcomings and solve existing problems. About $18 \%$ of the respondents found it as a positive lesson of the pandemic that remote office work is feasible and efficient. Again, the observed effect is significantly correlated with the type of the industries $\left(\chi^{2}=57.803, \mathrm{df}=30, P=0.002\right)$ but not their location or number of employees.

In response to a question about their expectation of the first quarter of 2021 function and development, a minority (about 17\%) of the respondents were optimistic. Nearly $40 \%$ expected a balance of income and expenditure whereas another $40 \%$ expected loss or serious loss. Only 6 respondents expected bankruptcy. Based on the $\chi^{2}$ analysis, the firms from the peninsula are more optimistic than the industries located in East Malaysia $\left(\chi^{2}=14.598, \mathrm{df}=4, P=0.006\right)$. The type of industry is also highly correlated with the prospect $(\mathrm{Phi}=0.696)$ whereas the firm size seems to be not associated with the anticipated future.

Cutting pay and jobs, as well as delaying the payments were the main methods of coping with cash flow shortage, as most of the respondents stated (Figure 3). The respondents were asked about the self-help measures the firm has taken so far. Increased online operations and finance applications were the most popular measures (Table 4).

Tax relief was the expectation of many of the respondents from the government $(51 \%)$ and, to a less extent, to provide subsidies for rent and utilities. Among the 379 firms, 52 firms (13.7\%) felt that the government should stimulate consumption to help them overcome the difficulties.

The pandemic has facilitated the tendency of the participants of current study towards online commerce. Only about $10 \%$ of the respondents were unwilling to adopt this transformation (Table 5). The type of industry shows a strong association with the willingness to transform into online commerce $\left(\chi^{2}=\right.$ 88.532, $\mathrm{df}=60, P=0.010, \mathrm{Phi}=0.48)$. 
Keshavarzi, F. et al.

Table 1. Frequency of the intensity of COVID-19 impact on the firms' business operations

\begin{tabular}{|l|l|}
\hline \multicolumn{1}{|c|}{ Responses } & Frequency (\%) \\
\hline Very serious impact, leading to serious difficulties in business operations and bankruptcy & $53(14.0)$ \\
\hline Great impact, operations barely maintained & $123(32.5)$ \\
\hline Small impact, some difficulties in business operations, but overall stability & $160(42.2)$ \\
\hline No significant impact & $23(6.0)$ \\
\hline Positive impact, providing new opportunities for development & $20(5.3)$ \\
\hline Total & $\mathbf{3 7 9}(\mathbf{1 0 0})$ \\
\hline
\end{tabular}

Table 2. Impact of the pandemic on firm's technological innovation

\begin{tabular}{|l|l|}
\hline \multicolumn{1}{|c|}{ Responses } & Frequency (\%) \\
\hline Unable to cooperate with other departments to carry out part of Research \& Development & 166 (43.8) \\
\hline Determined to invest more in technological innovation after being better aware of the firm's & $103(27.2)$ \\
\hline self-development problems & \\
\hline Research \& Development process may affect the launching process of new product & $60(15.8)$ \\
\hline Unable to recruit suitable Research \& Development personnel & $50(13.2)$ \\
\hline Total & $\mathbf{3 7 9}(\mathbf{1 0 0})$ \\
\hline
\end{tabular}


Table 3. Impact of the pandemic on the supply of raw materials, spare parts and other production and operation materials

\begin{tabular}{|l|l|}
\hline Responses & Frequency \\
\hline Total disruption of supply & $23(6.1 \%)$ \\
\hline Supply barely maintains production & $47(12.4 \%)$ \\
\hline Supply shortage & $93(24.5 \%)$ \\
\hline Normal supply & $99(26.1 \%)$ \\
\hline Satisfactory supply & $117(30.9 \%)$ \\
\hline Total & $379(100.0 \%)$ \\
\hline
\end{tabular}

Table 4. Deployed self-help measures to overcome the crisis

\begin{tabular}{|l|l|}
\hline Responses & Frequency \\
\hline Applied for financing & $100(26.4 \%)$ \\
\hline Cut pay and jobs & $126(33.3 \%)$ \\
\hline Implemented a remote office (digital office) & $43(11.4 \%)$ \\
\hline Increased online operations & $110(29.0 \%)$ \\
\hline Total & $379(100.0 \%)$ \\
\hline
\end{tabular}


Keshavarzi, F. et al.

Table 5. Willingness to transform to online commerce

\begin{tabular}{|l|l|}
\hline Responses & Frequency \\
\hline Very willing & $61(16.1 \%)$ \\
\hline Reasonably willing & $141(37.2 \%)$ \\
\hline Willing & $136(35.9 \%)$ \\
\hline Unwilling & $28(7.4 \%)$ \\
\hline Very unwilling & $13(3.4 \%)$ \\
\hline Total & $379(100.0 \%)$ \\
\hline
\end{tabular}

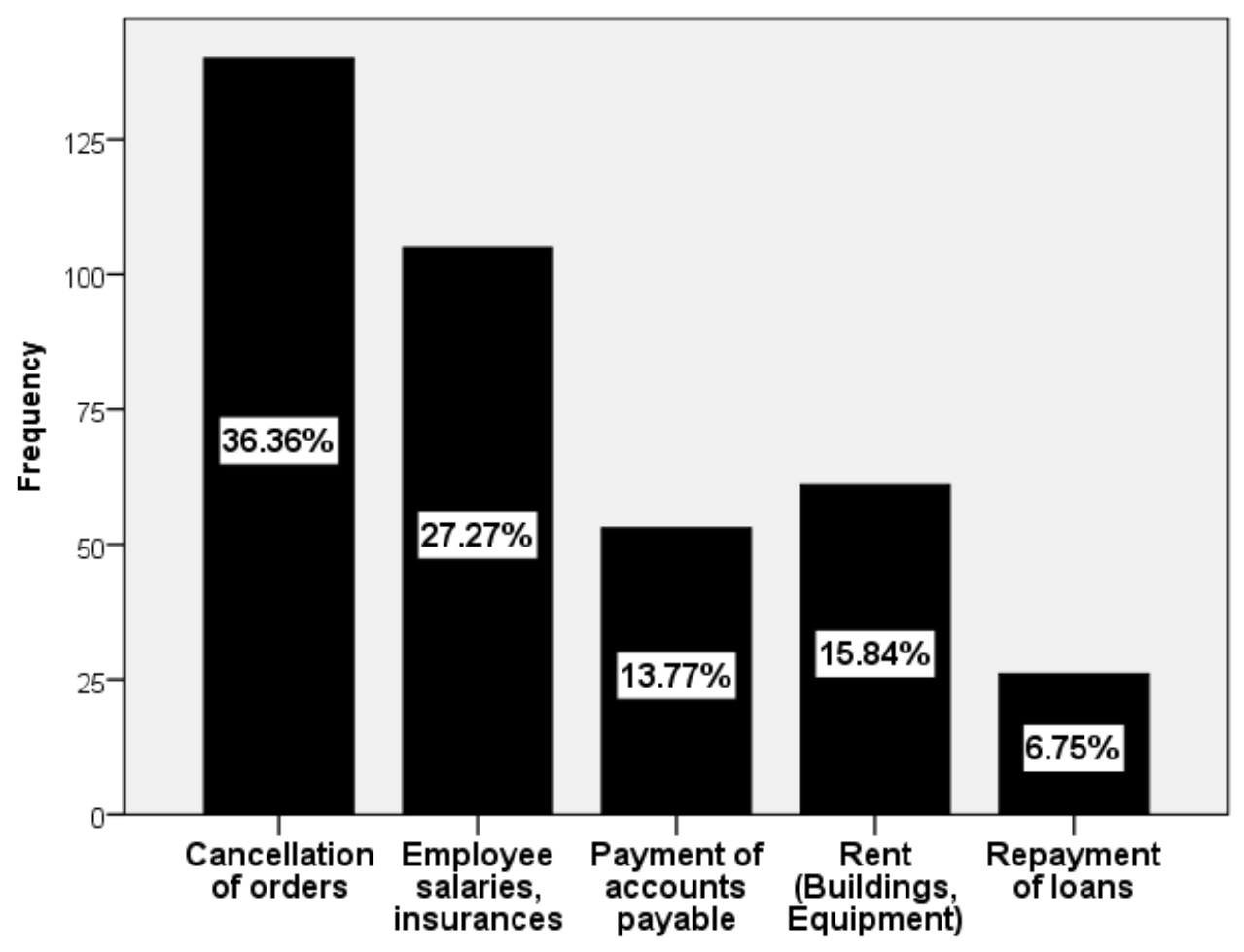

Figure 1. Types of operating pressures 
Table 6. Impact of the pandemic on the firms' recruitment policies

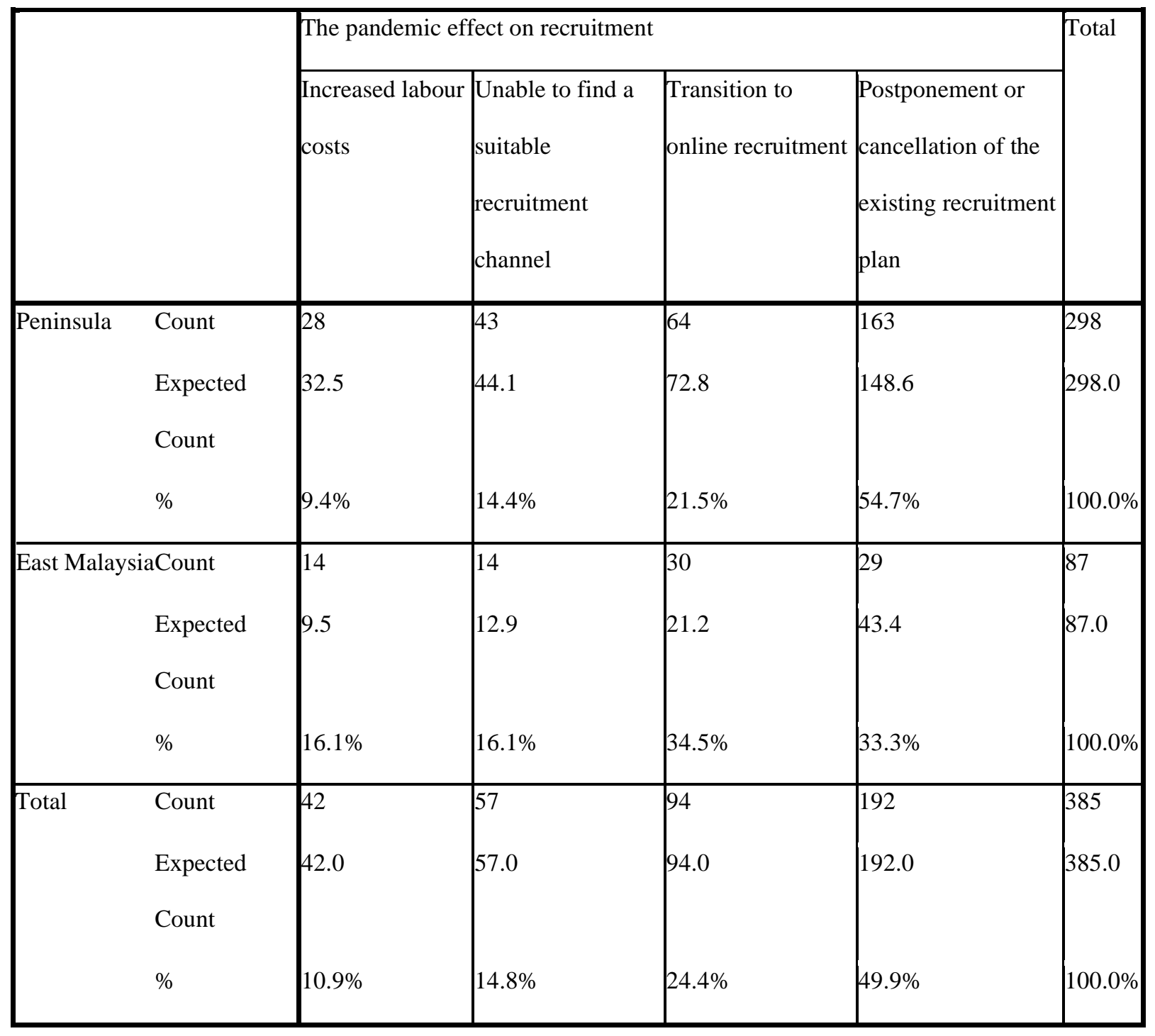




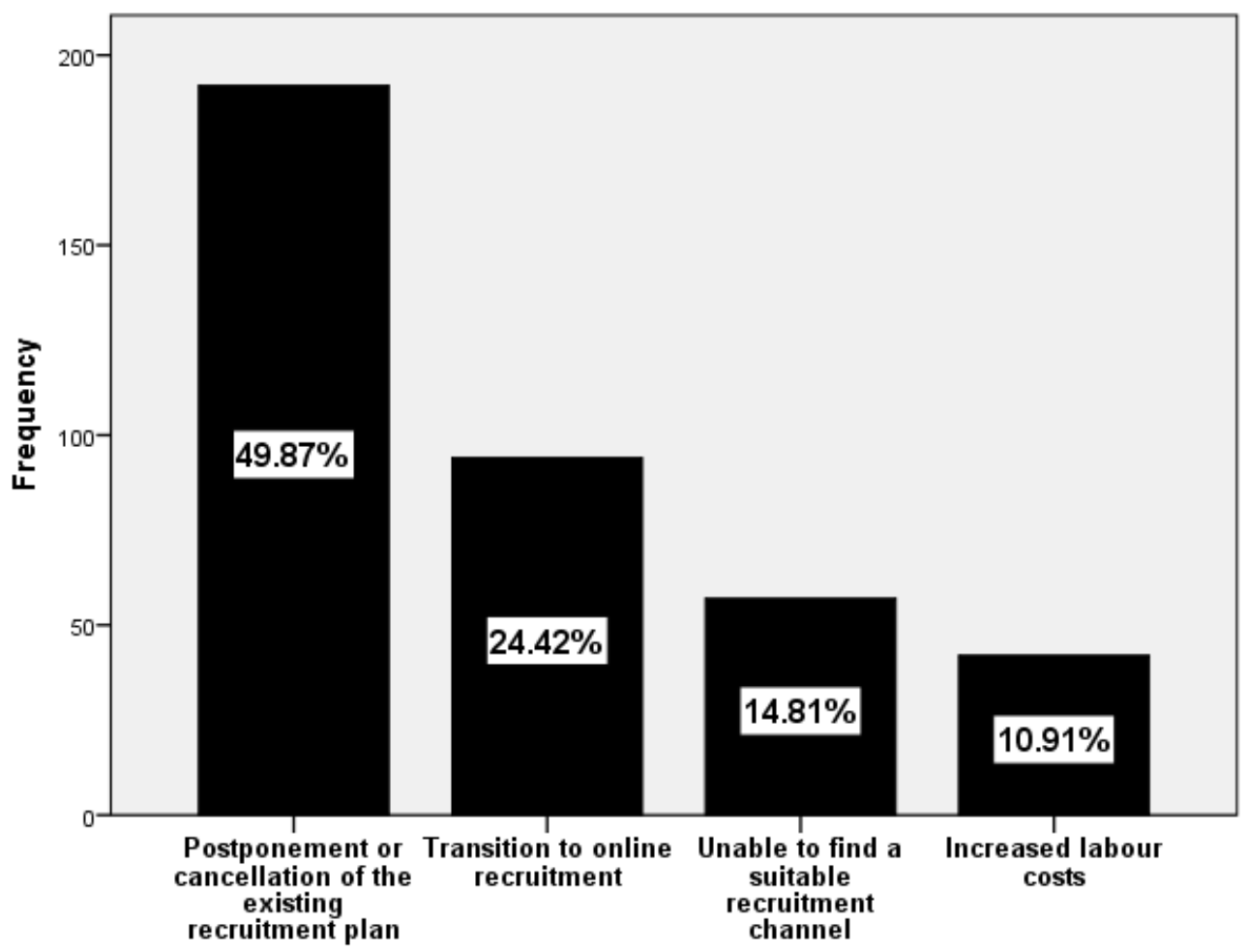

Figure 2. Impact of pandemic on firms' recruitment

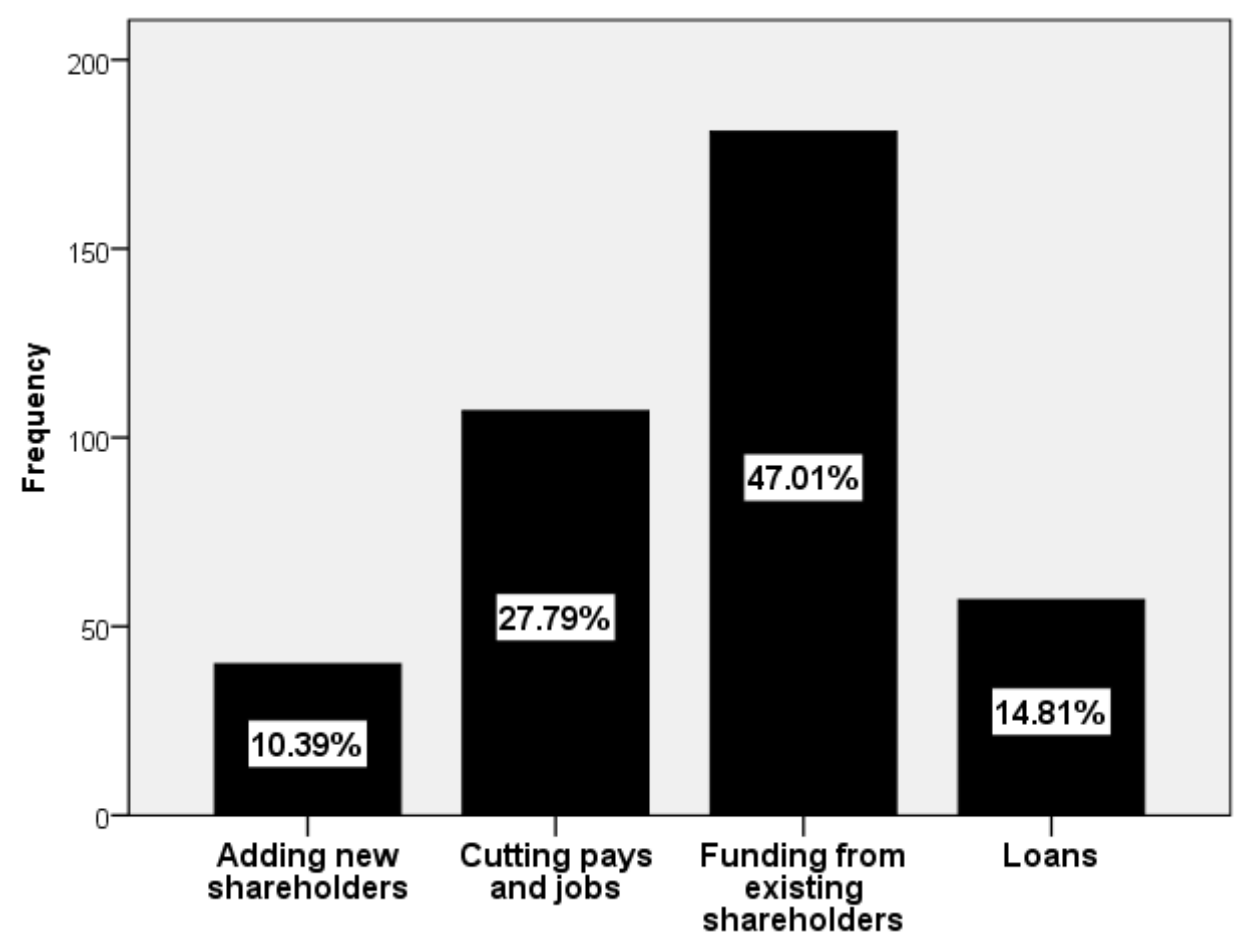

Figure 3. Methods of coping with the cash flow shortage 


\section{Discussion}

The enforcement of the Movement Control Order (MCO) was initiated on $18^{\text {th }}$ of March 2020 which restricted travelling and greatly influenced economic activities (9). The impact of MCO on some sections of the Malaysian economy, such as hospitality and tourism, has been a major and devastating effect (10). The other businesses have been affected to some extent, not only by the local MCO and the destructive domino effect, but also due to the global impact of the pandemic on market demand. The emergency stimulus plan of the Malaysian government was about $17 \%$ of the gross domestic product, more than the UK (16\%) and the USA (11\%) (11). Strict initial MCO, followed by successive enhancements in the reopening of the market operations, in addition to the stimulus plan, allowed many Malaysian firms to survive in this tough period. The Malaysian economy has tight connections with international markets, especially in terms of tourism and workforce. Therefore, it is expected that tourism and hospitality, construction, and farming will be amongst the front-line victims of the pandemic.

The findings of the current study show that the deployed measures, have been able to save the Malaysian economy from a major collapse. The impact of the pandemic on different firms and sectors' operations, has been majorly due to the type of business, rather than the firm's size or location. For example, the greatest negative impact was reported by tourism, followed by construction/engineering and clothing/textile firms. Some sectors, such as food and cosmetics, reported moderate impact, whereas the healthcare-related firms benefited from the pandemic, positively.

The response of East Malaysia to the pandemic regarding workforce problems is quite different from the peninsula (Table 6). Where peninsula-located firms tend to cancel the existing recruitment plans, the Eastern Malaysian firms report difficulties in accessing their required workforce that is now more costly, as well. The observed difference could be due to the type of industry executives who responded to the survey. More agriculture/fishery/forestry executives are from East Malaysia where no one is from the clothing/textile sector, for instance. This is in line with the lower contribution of Eastern Malaysia in general consumption, due to the lower level of citizens' income despite high contribution in agricultural and industrial production (12).

The cancellation of orders was the most reported $(36.7 \%)$ operating pressure, followed by employee salaries and insurance $(27.7 \%)$. Cancellation of orders by customers potentially raises the total system costs through unpredicted inventory and leads to complications in the supply chain $(13,14)$. The recruitment plan is directly affected by operating pressures, including the cancellation of orders. Almost half of the responding firms $(50.4 \%)$ postponed or cancelled their existing recruitment plans due to the pandemic.

The COVID-19 pandemic has provided areas of progress for some of the businesses, despite all the destructive impacts. It seems that the huge potential of the internet and online management of businesses has been discovered in a very short period. The $\chi^{2}$ analysis of current study data shows that the reported positive impacts are correlated with the type of industry. For example, auditing/accounting firms reported a high tendency for remote office working, whereas agriculture/fishery/forestry firms are strongly against this approach. Almost $45 \%$ of the respondents believed that the pandemic contributed to enhancement in their information and digital constructions. Previously, it was reported that one of the prominent examples can be seen in the educational field in which the teaching and learning process is converted to online from face-to-face mode (15). However, of 40 participants who were coming from the education/training/research cluster, the actual count does not show a difference with the expected count in the $\chi^{2}$ analysis. Although the educational operations have highly shifted into online activities, perhaps the finding reflects the tendency of the educational firms' executives towards face-to-face learning processes.

Many of the MCO restrictions that were imposed in March 2020, were lifted gradually under the Conditional Movement Control Order (CMCO). The enhancements allowed businesses to return to near normal activity, especially from January 2021. Probably, the Malaysian firms are optimistic about their future because of their survival and relative restoration of operations. About 38 of the firms believed that their firms would experience a balance of income and expenditure despite the pandemic. However, $29.3 \%$ of firms expect that their firms will suffer losses in the first quarter of 2021. This may be explained by reduced income and spending power of consumers. Moreover, some economic sectors are still under restriction during this $\mathrm{MCO}$ and $\mathrm{CMCO}$. The anticipation of the first quarter of 2021 in Eastern Malaysia is not as optimistic as the peninsula. Where only $0.7 \%$ of the respondents expected bankruptcy in the peninsula, $4.6 \%$ of East Malaysia firms reported 
such an expectation. On the other hand, $41.6 \%$ of peninsular firms expected a balance, whereas in East Malaysia, only $28.7 \%$ of the firms anticipated a balance. Nevertheless, the type of industry shows a significant correlation with the firm's prospective first quarter performance. The hotel/tourism sector exhibited the most pessimistic view, followed by transportation/logistics. The highest expectation of profit belongs to the banking/finance/insurance sector, followed by automotive/spare parts and healthcare (57.1\%, $40.0 \%$ and $31.8 \%$, respectively).

The way the firms responded to the questions about how to cope with the cash flow shortage shows that the East Malaysia firms are significantly more dependent on loans and government support, compared to the peninsular firms $(29.9 \%$ versus $10.4 \%, \mathrm{P}<0.001)$. In general, $30.3 \%$ of firms stated that they could deal with a cash flow shortage by delaying payment, followed by $27.7 \%$ of firms cutting pay and jobs. This is in line with a survey carried out by JobStreet website that shows half of the respondents have experienced a negative impact on their salaries and remuneration during this pandemic (16). Employee job cuts, such as reduced working days or hours, forced annual leaves, and unpaid leaves, are also among the measures used to address cash flow issues. Most firms choose delaying payment as a method to cope with cash flow shortages as it is a less extreme measure compared to cutting pay and jobs.

According to the results of a research initiated by Google company, COVID-19 has forced South-East Asians to approach digital services, dramatically. As the report stated, about $36 \%$ of all digital service consumers are new to the service due to COVID-19 and e-commerce has surged by $87 \%$ in 2020 . The search trend for online-selling related queries has also increased by 5 times (17). This is in line with the findings of the present study where nearly $90 \%$ of the firms show willingness to transform to online commerce.

By the way, self-help measures may not be adequate to save all firms and businesses unless the government policies and measures consider the complicated conditions. Where about $51 \%$ of the participants expected the government to reduce, exempt or postpone value-added tax, income tax, insurance premiums and other taxes, several tax measures have been implemented by the Malaysian government. This includes a special tax deduction of up to RM 300,000 for renovation and refurbishment of business premises until 31 December 2021 (18). Until 30 June 2021, both small and medium-sized enterprise (SME) and nonSME tenants are eligible for special tax relief on business premise rentals of at least $30 \%$ (19). Furthermore, hotel operators, theme parks, convention centres, shopping malls, domestic flight company offices, and tour agencies benefited from a $10 \%$ discount on electricity bill until March 2021, whereas up to a $9 \%$ discount is available for all users until June 2021 (19).

\section{Limitations of this study}

The online convenient sampling perhaps does not provide the best representativeness of the target population. Ideally, the respondents should be selected proportionally from the entire sampling frame to ensure a good representative of the whole population is recruited. The recruited sample of this study has successfully covered all industry categories that the UNDP report had provided. But the authors cannot claim that the proportion of the recruited respondents follows the actual proportions regarding the firm's size, location, or field of operation. Purposive sampling may improve study reliability when representatives from certain industries are absent. The firms that are not interested in online marketing are likely to miss out on this study, as well. Moreover, this study does not provide a picture of the public sector operation and its challenges.

\section{Conclusion}

The impact of COVID-19 on Malaysian firms is quite heterogeneous. Almost half of the firms experienced a small impact on overall stability. But nearly half of the firms had to postpone or cancel their existing recruitment plans due to the pandemic. Under the effect of COVID-19, many firms are willing to transform into online commerce. Most of the indicators of the firms' operation are not affected by the firms' location or size but their type of business. Where businesses like tourism are greatly damaged, some others, like healthcare firms, have benefitted from the condition. Currently, about one-third of the firms are critically in need of government support and financial aid to survive.

\section{References}

1. Morgan, A.K., Awafo, B.A,, Quartey, T. The effects of covid-19 on global economic output and sustainability: Evidence from around the world and lessons for redress. Sustainability: Science, Practice and Policy 2021;17(1):77-81. 
2. Eichengreen, B. The human-capital costs of the crisis. Project Syndicate 2020;10:2020. Available from: https://www.projectsyndicate.org/commentary/covid19-pandemicerosion-of-human-capital-by-barry-eichengreen2020-04?barrier=accesspaylog

3. National Bureau of Statistics of China (NBoSo). Preliminary accounting results of GDP for the Fourth quarter and the whole year of 2020. [cited 2021 May 12]. Available from: http://www.stats.gov.cn/english/PressRelease/202101 /t20210120_1812680.html

4. Bureau of Economic Analysis, US Department of Commerce [Internet]. Fourth quarter and year 2020 (advance estimate). [cited 2021 May 12]. Available from: https://www.bea.gov/news/2021/grossdomestic-product-4th-quarter-and-year-2020advance-estimate

5. Tahajuddin, S., Sulaiman, N.N. Malaysian government choice of fiscal and monetary policies during covid-19 pandemic: Preliminary insight. Int J Advance Engineer Manage 2021;3(1):248-53.

6. Flanders Trade [Internet]. Corona virus - the situation in malaysia 2021 [cited 2021 April 10]; Available

from: https://www.flandersinvestmentandtrade.com/export/ nieuws/corona-virus-\%E2\%80\%93-situationmalaysia.

7. Zou, P., Huo, D., Li, M. The impact of the covid-19 pandemic on firms: A survey in guangdong province, china. Glob Health Res Policy 2020;5(1):1-10.

8. United Nations Development Programme in China. Assessment report on impact of covid-19 pandemic on chinese enterprises, April 2020. [cited 2021 May 12]. Available from: https://www.cn.undp.org/content/china/en/home/libra ry/crisis_prevention_and_recovery/assessmentreport-on-impact-of-covid-19-pandemic-on-chineseente.html

9. Shah, A.U.M., Safri, S.N.A., Thevadas, R., Noordin, N.K., Abd Rahman, A., Sekawi, Z., et al. Covid-19 outbreak in malaysia: Actions taken by the malaysian government. Int J Infect Dis 2020;97:10816.
10. Karim, W., Haque, A., Anis, Z., Ulfy, M.A. The movement control order (mco) for covid-19 crisis and its impact on tourism and hospitality sector in malaysia. Int Tourism Hospitality J 2020;3(2):1-7.

11. Umair, S., Waqas, U., Faheem, M. Covid-19 pandemic: Stringent measures of malaysia and implications for other countries. Postgrad Med J 2021;97(1144):130.

12. Tey, N.P., Lai, S.L., Ng, S.T., Goh, K.L., Osman, A.F. Income inequality across states in malaysia. Planning Malaysia 2019;17(10).

13. Ohta, H., Furutani, T. Effect of customer order cancellation on supply chain inventory. J Chinese Inst Industr Engineer 2004;21(1):40-5.

14. Son, J., Kang, J.H., Jang, S. The effects of out-ofstock, return, and cancellation amounts on the order amounts of an online retailer. J Retailing Consumer Service 2019;51:421-7.

15. Vargo, D., Zhu, L., Benwell, B., Yan, Z. Digital technology use during covid-19 pandemic: A rapid review. Hum Behav Emerg Technol 2021;3(1):13-24. 16. JobStreet. Covid-19 job report 2020. [cited 2021 May 9]. Available from: https://www.jobstreet.com.my/en/cms/employer/wpcontent/themes/jobstreet-

employer/assets/loa/report/my/JobStreet-COVID-19Job-Report-Malaysia-Sept-2020.pdf.

17. Davis, S., Sipahimalani, R., Baijal, A., Cannarsi, A., Neves, N.C., Dhanuka, R. E-conomy sea 2020 at full velocity: Resilient and racing ahead-What marketers need to know about this year's digital shifts. [cited 2021 May 9]. Available from: https://www.thinkwithgoogle.com/intl/enapac/consumer-insights/consumer-journey/economy-sea-2020-resilient-and-racing-ahead-whatmarketers-need-to-know-about-this-years-digitalshifts/

18. KPMG. Malaysia: Tax developments in response to covid-19. [cited 2021 May 9]. Available from: https://home.kpmg/xx/en/home/insights/2020/04/mal aysia-tax-developments-in-response-to-covid19.html.

19. Malaysian Treasury, Government [Internet]. Budget 2021. [cited 2021 May 9]. Available from: http://belanjawan2021.treasury.gov.my/manfaat/inde x.php/en/permai-en. 